\title{
Vormt moderne antropologie een probleem voor het Christelijk geloof?
}

\begin{abstract}
Author:
Luco J. van den Brom ${ }^{1,2}$

Affiliations:

${ }^{1}$ Protestant Theological University (PThU), the Netherlands \& Faculty of Theology and Religious

Studies, University of

Groningen, the Netherlands

${ }^{2}$ Department of Systematic Theology and Christian

Ethics, University of Pretoria

South Africa

Note:

Prof. Dr. Luco van den Brom is participating as research fellow of Prof. Dr Johan Buitendag, Dean of the Faculty of Theology at the University of Pretoria, South Africa. This article represents a reworked version of a paper read at an Expert Seminar on 'Anthropology in an Age of Science' with scholars in Systematic Theology of the Protestant Theological University and the Faculty of Theology of the University of Pretoria (on 08 September 2011 in Pretoria).
\end{abstract}

Correspondence to: Luco van den Brom

Email:

ljvandenbrom@home.nl

Postal address:

Slauerhofflaan 80, 9752 HD

Haren, the Netherlands

Dates:

Received: 22 Jan. 2013

Accepted: 06 Apr. 2013

Published: 25 June 2013

How to cite this article: Van den Brom, L.J., 2013,

Vormt moderne antropologie een probleem voor het Christelijk geloof?', HTS

Teologiese Studies/ Theological Studies 69(1), Art. \#1924, 10 pages. http://dx.doi.org/10.4102/ hts.v69i1.1924

Read online:
Does modern anthropology pose a problem to the Christian faith? Contemporary scientific anthropology proposes a naturalistic conception of human personhood because of humankind's place somewhere in the larger evolutionary process of life. Some authors use the theory of biological evolution to explain phenomena in other areas as well, and due to its success suggest it has universal application in cultural and religious studies too, as if it were a theory of everything. Darwin's idea of a common origin of all life undermined a supposed superiority of humankind. It signalled the end of an Aristotelian metaphysical notion of classification and constituted a real blow for classical individualistic anthropology. Dawkins explains religion in terms of empirical immanent biological processes in the human brain. He views religious ideas as 'memes' that act like an infectious virus in mental processes. His hypothesis seems to be a relapse into the old Aristotelian pattern. Michael Persinger interprets religion as an internal physiological state of an individual brain and reduces the language of mental concepts to physiological states of a material brain. Persinger's, and also Dennett's, materialistic view presupposes a God's Eye Point of View as an Archimedian perspective outside the world. If a God exists, the neurologists Newberg and d'Aquili argue that he needs a point of contact within our brain: the God spot. Sociobiologists Edward Wilson and David Wilson consider religion a form of group adaptation, because cooperating individuals show the primary benefits of cooperation and altruistic behaviour, just as social insects. Religion is an evolutionary support of altruistic instincts and creates a social infrastructure to benefit a cooperative society. However, social insects merely act on their instincts whereas human beings can act intentionally even against their primary instincts, because of motives for altruist practices inspired, for example, by the narratives and concepts of a Christian tradition. The communion of saints does not take place merely because of a social instinct, but because of the shared motive of the community as a whole, that is, the body of Christ, which acts altruistically irrespective of persons, including outsiders!

\section{Inleiding}

Eigentijdse mensbeelden die vanuit de natuurwetenschap zoals de biologie maar ook vanuit de neurologie voorgesteld worden, vertonen veelal een deterministische structuur. Deze deterministische structuur zien vele natuurwetenschappers als het (voorlopige) eindresultaat van de menselijke soort waartoe het evolutionair proces op dit moment geleid heeft. Deze mensbeelden blijken geregeld in publieke debatten voorondersteld te worden als breed geaccepteerd gemeengoed. Ook in populaire conversaties zijn deze vaak aanwezig omdat zij met intellectueel doordachte en algemeen toegankelijke argumenten worden gepresenteerd. Dat is wel eens anders geweest. Het verhaal gaat dat in 1860 op een vergadering van de British Association in Oxford Samuel Wilberforce, de plaatselijke bisschop, Thomas Huxley, een pleitbezorger van Darwins recentelijk gepubliceerde theorie van de afstamming van de biologische species, publiekelijk uitdaagde omtrent veronderstelde consequenties van diens nieuwe mensbeeld. Hij zou Huxley gevraagd hebben of deze de voorkeur eraan gaf zich voor te stellen zelf aan de kant van zijn grootmoeder van een aap af te stammen dan wel aan de kant van zijn grootvader. Huxley zou triomfantelijk Wilberforce van repliek hebben gediend: hij zou liever van een aap willen afstammen dan van een bisschop die zich met zijn ambtelijk gezag meent te moeten uitlaten over zaken waarvan hij hoegenaamd geen verstand heeft. Of Huxley het debat echt hiermee won, zoals onder andere Bertrand Russell het voorstelt, is omstreden (zie Brooke \& Cantor 1998:35-36).

Wat er in 1860 op die vergadering van de British Association gebeurde, laat vooral een culturele verandering zien in het denken over wie/wat het gezag heeft in kwesties van kennisclaims: Is dat de kerk a priori als vanouds hoedster van de 'Waarheid' of zijn dat eigentijdse empirische onderzoekers? We kunnen ons daarbij afvragen of hier wel gelijkwaardige uitspraken met elkaar worden vergeleken. Op zichzelf gaf Huxley retorisch de bisschop hiermee een vernietigend

Copyright: (c) 2013. The Authors. Licensee: AOSIS OpenJournals. This work is licensed under the Creative Commons Attribution License. 
antwoord, maar tegelijkertijd aanvaardde hij daarmee wel de karikaturale voorstelling die de bisschop van Darwins theorie gaf: 'Darwin says that men are descended from monkeys!' Bertrand Russell merkt in 1935 met ontzetting op dat 'theologen en ongeschoolde mensen' vooringenomen zich op één aspect van die theorie geconcentreerd hebben, namelijk de afstamming van de mens van lagere diersoorten (Russell [1935] 1971:76-81). ${ }^{1}$ Russell constateert echter anderzijds ook dat verschillende intellectuelen in het denkklimaat van de 19 e eeuw de idee van een biologische evolutie aanvoerden als bevestiging van het algemene beeld van een wetenschappelijke en industriële vooruitgang. Zelf beseft Russell echter heel goed dat met dezelfde wetten wij zowel de groei als ook het verval van organismen beschrijven. Het is nu moeilijk in te zien hoe zich moderne theologen indertijd voorstelden dat Gods plan zich via een evolutionair proces ontvouwt juist met het oog op het ontstaan van mensen.

Terwijl dieren onderling elkaar kwelden, verschenen ook nog de mensen die de dieren in wreedheid overtroffen. Waarom realiseerde de Schepper zijn plan niet regelrecht in plaats van toe te zien op een lijdensproces in het dierenrijk totdat eindelijk de menselijke species op het wereldtoneel verschijnt? Dat leggen moderne theologen blijkbaar niet aan Russell uit. Hij poneert dan ook zelf nadrukkelijk: 'From evolution, so far as our knowledge shows, no ultimately optimistic philosophy can be validly inferred' (Russel [1935] 1971:81). Daarmee lijkt Russell zich uit te spreken tegen een achteloos gebruik van dergelijke grote natuurwetenschappelijke theorieën op een ander terrein dan waarvoor zij ontworpen zijn, zoals bijvoorbeeld voor cultuurfilosofische of ideologische doeleinden. Russell wijst hier op een belangrijk punt, want daarvoor hebben we ons eerst rekenschap te geven van de betekenis en ook de aard van de analoge variabelen in een nieuw veld van discussie waarvoor men bijvoorbeeld de evolutietheorie als verklaring of verheldering gaat gebruiken. Dat vraagt om zorgvuldige interpretatie en een hermeneutiek die aandacht geeft aan vragen over wat de analogie wel of niet meer toelaat. Een theorie waarmee men successen binnen een breed onderzoeksgebied boekt, zoals bijvoorbeeld voor alle ons bekende levensvormen, nodigt uit om haar de rol te laten vervullen van een universeel verklaringsmodel voor 'alles', als betrof het een 'theory of everything'. Een dergelijke theorie heeft als doel in een eenvoudig mathematische formule een allesomvattende vergelijking te leveren waaruit we uiteindelijk het complete heelal kunnen afleiden. ${ }^{2}$

De volgende stap houdt dan in dat zulk een 'theory of everything', zelf ook onderdeel van dat heelal, nu ook zichzelf verklaart; bovendien ook waarom die theorie nu pas verschijnt. Iets analoogs zien wij met de evolutietheorie

1.Russell merkt wel op dat theologen sneller (!) de consequenties van de nieuwe zienswijze inzagen dan haar voorstanders: mensen hebben onsterfelijke zielen en apen niet, terwijl Christus voor mensen is gestorven, niet voor apen.

2.Een bekend voorbeeld is Hawking (1988:164-174). Levert die theorie een beeld van een zichzelf scheppend heelal op, dan is het een tweede vraag of dat heela ook de reden bevat waarom het $z o$ bestaat zoals het bestaat. Een heelal dat zelf de reden bevat waarom het er op deze specifieke wijze is en niet op een andere manier, verklaart zichzelf. Het verklaart ook dat waar en wanneer een 'theorie over alles' in het heelal zal ontstaan. Hawkings theorie zou dan verklaren waarom Hawking en zijn theorie op het geëigende moment hadden moeten ontstaan. gebeuren, wanneer deze buiten de biologie in andere wetenschapsgebieden als verklaringsmodel gebruikt wordt, zoals voor beschouwingen over de ontwikkeling van culturen, waarmee het ontstaan en veranderingen in allerlei kunstvormen, van godsdiensten en vormen van religieuze rivaliteit verklaarbaar kunnen worden. Daarbij benadert men religie als een empirisch of binnenwereldlijk fenomeen dat zich binnen een menselijk individu of juist binnen een groep van individuen voordoet. In het vervolg zal ik ingaan op het individualistisch mensbeeld in een empirisch darwinistische benadering zoals die tot uiting komt in Richard Dawkins' visie op religie als overdraagbaar virus. Daarna kijk ik naar een ander individualistisch mensbeeld dat in de zogenaamde 'neurotheologie' naar voren komt: die zoekt naar een universeel gedeelde biologische basis voor religie in het menselijk brein. Vervolgens geef ik aandacht aan het alternatieve mensbeeld dat wordt verondersteld in David S. Wilsons darwinistische visie op religie als groepsadaptatie. Deze benadering ziet een groep van individuen zich als een eigenstandig individu gedragen. Dit doet theologen en antropologen aan de voorstelling van de corporate personality denken (Robinson 1956:87-88, 163-164, 203-204).

\section{Klassiek: De mens als centrum gedacht}

Voor de antropologie vinden wij in de klassieke theologie een differentiërende benadering waarbij aan 'de mens' diverse aspecten worden toegekend. Zo kenden de Griekse patres een trichotomisch mensbeeld dat een onderscheid tussen de geest, de ziel en het lichaam van de mens maakt, terwijl de Westerse theologie meer een dichotomisch mensbeeld hanteerde dat 'slechts' twee fundamentele begrippen, ziel en lichaam, gebruikt. Over de lichamelijkheid werd misschien in navolging van Plato of Aristoteles wel verschillend gedacht, maar bij 'de mens' dacht men allereerst aan een rationeel denkend levend wezen (animal rationale). ${ }^{3}$ Daarbij krijgt men de indruk dat de verstandelijke aspecten de nadruk krijgen terwijl lichamelijke activiteiten bijkomstig lijken. Dit zien we in de bekende omschrijving die Boethius van de menselijke persoon als individueel denkend wezen geeft, nader onderstreept. ${ }^{4}$ Daarmee geeft hij feitelijk een volledig abstracte omschrijving van de menselijke persoon als betrof het een afzonderlijk denkend 'object' dat separaat van andere objecten gedacht kan worden omdat het individueel bestaat of functioneert. Zo bezien zegt deze omschrijving dat het unieke van de mens in zijn binnenwereld bestaat die redelijk denkt: een substantie met als bijkomende eigenschap (accident) 'redelijk denkend'. Door de mens te abstraheren als individu

3.Aristoteles stelt dat de mens een levend wezen met logos begiftigd is (zoon logon echon) dat zich van iets rekenschap kan geven en daarover redelijk kan spreken (zie bijv. Politica 1.2, 1253a 9). Plato heeft daarentegen een mensbeeld waarin de ziel als de eigenlijke mens wordt beschouwd die echter door het lichaam gevangen gehouden wordt (zie bijv. Phaedo 82E, 83D).

4.Anicius Boethius: 'persona est naturae rationalis individua substantia'; in Contra Eutychen et Nestorium III 4-5. 'Persoon' is de individuele substantie van een met rede begiftigde natuur. 'Natuur' geeft het kenmerkende van een zaak aan en 'substantie' duidt het continue aan dat blijft van een zaak bij alle kwalitatieve veranderingen. Dit individuele persoonsbegrip wordt in zijn intellectueel testament veranderingen. Dit individuele persoonsbegrip wordt in zijn intellectueel testament eraan moet herinneren dat hij meer (aliud) is dan een animal rationale et mortale, maar georiënteerd op het liefdevolle beleid van de Conditor (Schepper): dat is logisch een opmerkelijke verschuiving van een essentialistische of aristotelische voorstelling van persoon naar een meer relationele voorstelling. 
van de omgeving lijkt Boethius een wissel in de traditie van substantieel denken om te zetten dat mensen als losstaande 'denkdingen' beschouwt ter onderscheiding van dingen met lichamelijke kenmerken, zoals dieren. Zo beschouwd zet de Cartesiaanse opdeling van de werkelijkheid tussen de sfeer van de res cogitans en van de res extensa bij Boethius in, waarbij ook weer het mentale of cerebrale de prioriteit krijgt boven het lichamelijke. Die prioriteit van de mentale sfeer van de res cogitans culmineert in zijn these cogito ergo sum (Principia Philosophiae I.10), terwijl Descartes over het menselijk lichaam analoog aan het dierlijke als een soort 'machine' spreekt, zonder daarmee het lichaam tot een automaat te reduceren.

Met de voorstelling van de mens als denkend wezen, primair door mentale activiteiten getypeerd, maakt ook Hegel onderscheid tussen mensen en dieren: de mens is een 'bewust' wezen oftewel 'geest'. Het bijzondere van mensen komt in de ervaring van een voortdurend 'bewustzijn' tot uitdrukking waarmee een menselijk individu zich van 'zichzelf' in onderscheid van de substantiële werkelijkheid die het omringt, bewust wordt. ${ }^{5}$ Hier komt de mens bewust tot een ontwerp van de omringende wereld waarin zijn 'ego' centraal staat in zijn oriëntatie overeenkomstig het Cartesiaans denkend ego. Voor een dergelijke voorstelling van de individuele mens als centrum betekent de publicatie van het beroemde boek van Charles Darwin een geweldige schok. In dat boek, getiteld On the origin of species by means of natural selection betoogt hij immers dat (mogelijk) alle levende organismen in hun variaties uit eenzelfde 'voorouder' of oorsprong kunnen zijn ontstaan; dat geldt ook mensen: zij kunnen zich niet op een unieke oorsprong laten voorstaan. Hij levert een theorie van natuurlijke selectie die voor de meeste biologen gemeengoed is geworden: de voorstelling dat alle levende wezens in hun diverse variaties zich hebben ontwikkeld uit een gemeenschappelijke oorsprong. Darwins gedachtegang gooide nu anderhalve eeuw geleden (1859) een wereldbeeld met vaststaande 'feiten' en opvattingen ondersteboven.

Darwin betwistte een traditioneel wetenschappelijke overtuiging die in de empirische wetenschap met de metafysische premisse werkte dat alle species altijd en overal onveranderlijk stabiel zijn geweest. Dit betreft de aristotelische gedachte dat de natuurlijke wereld uit onveranderlijke, stabiele essenties bestaat, wat een statisch wereldbeeld impliceert. Darwins gewaagde voorstel veronderstelde een alternatief wereldbeeld waarin principieel sprake is van dynamische processen als basisstructuur. ${ }^{6}$ Daarbij ontstaan de levensvormen wel als soorten, maar zij kunnen zowel veranderen als ook weer verdwijnen. Niet

5. Hegel spreekt hier over het eeuwige bewustzijn in Begriff der Religion, wat ik begrijp als 'voortdurend' bewustzijn. Het individu weet als 'ik' dat bewust is, dat primair alleen dit ik zeggen kan 'dit' en 'hier' in zijn oriëntatie op of in de wereld (Hege [1807] 1937: I.79-80).

6.Aristoteles heeft voor de wetenschap een scala naturae voorgesteld waarmee alle dieren geclassificeerd konden worden, eventueel hiërarchisch volgens eigenschappen (zie Lovejoy 1936:58-59), maar 'natuurlijke selectie' betekent nog niet progressie in een doelgerichte zin (Rosenberg \& McShea 2008:127-128);
Rom Harré betoogt dat Darwin met een model werkte dat analoog was aan de Rom Harre betoogt dat Darwin met een model werkte dat analoog was aan de
kunstmatige selectie bij het fokken van dieren of het kweken van planten, en noemde dit natuurlijke selectie (Harré 1972:176-177; Brooke 1998:30); in de 19e noemde dit natuurlijke selectie (Harre 1972:176-177; Brooke 1998:30); in de 19e
eeuw kwam in de natuurwetenschap aandacht voor de herleiding van verschijnselen tot hun oorsprong zoals in Darwins evolutietheorie (Van Brakel 1998:24, 106). alleen van individuele levende wezens kunnen we zeggen dat zij 'opgaan, blinken en verzinken', maar dat geldt ook voor de biologische soorten. ${ }^{7}$ Hier is ook geen onderscheid tussen mieren, muizen, honden, vissen, vinken, viooltjes of mensen. Voor godsdienst en theologie betekent dit het loslaten van de idee van de onveranderlijkheid van de soorten (dus van biologisch 'essentialisme' - Rosenberg \& McShea 2008:41-46), zodat een statische scheppingsvoorstelling onmogelijk en onbruikbaar wordt. Men kan immers biologische essentialisme theologisch funderen met de claim dat God de soorten stabiel heeft geschapen, waarin we zijn betrouwbaarheid kunnen herkennen. Analoog zag men traditioneel in de continuïteit der natuurwetten wel een grond voor het geloof aan de integriteit en de zorg van God. Neem bijvoorbeeld het teleologische 'argument from design', dat William Paley verdedigde in Natural Theology. ${ }^{8}$ Uit het subtiele kaartenhuis van dit design argument trok Darwin nu een metafysisch constitutieve kaart als overbodig weg. Dus de legendarische reactie van bisschop Wilberforce wordt geheel begrijpelijk omdat Darwins voorgestelde theorie nu als een 'scheermes van Ockham' werkte: de hypothese van de goddelijke horlogemaker om het bestaan van de stabiele levensvormen en van de natuurwetten te verklaren was overbodig geworden.

In de filosofie van de biologische wetenschap bediscussieert men de aard van de evolutietheorieën met behulp van de concepten selectie, adaptatie, geschiktheid (fitness) en de populatiestructuur van een soort. Selectie kan werken op voorwaarde dat (1) variatie mogelijk is, (2) opeenvolgende generaties in een genealogische structuur georganiseerd zijn en (3) diverse individuele exemplaren op verschillende wijze met hun omgeving in interactie komen. Terwijl de verschillende organismen hun genetische informatie ongeschonden doorgeven die noodzakelijk is voor reproductie van hun soort, blijken sommige exemplaren en organismen beter instaat (geschikt) om met hun omgeving in wisselwerking te treden dan andere. Dientengevolge leveren zij meer nageslacht en reproduceren op die manier ook numeriek meer ongeschonden genetische informatie: zij dragen de aan hun omgeving aangepaste informatie met zich mee (Rosenberg \& McShea 2008:15-19). In deze zinnen wordt internalistisch een empirisch mechanisme beschreven waarmee wij het ontstaan en de ontwikkeling van het leven kunnen bespreken. Daar staat tegenover een externalistisch ingericht teleologisch 'argument from design'. In dit laatste wordt vanuit de bedoeling van de goddelijke ontwerper (Schepper of Demiurg) geredeneerd, terwijl in de internalistische beschrijving het mechanisme per definitie geen externe bedoeling kan hebben, maar juist doelloos de diverse varianten produceert en lijkt uit te proberen. Empirisch blijkt daarbij dat sommige exemplaren van een species meer aan hun omgeving zijn aangepast dan andere en daarin makkelijker overleven en dan ook in grotere getale verschijnen. Deze 7.We hebben wel te bedenken dat het biologisch begrip 'soort' of species omstreden is
in vergelijking met 'natuurlijke soort' in de natuurkunde (Van Brakel 1998:106-109;
Rosenberg \& McShea 2008:41-42). Correspondeert met 'soort' een verzameling
van concreet bestaande wezens (walvis, eend) of duidt het een menselijke praktijk
van classificeren aan? Het laatste bestaat dan in ons denken (Bird 1998:95-120). 8.Zie Hick (1964:94-103). 
internalistische beschrijving vormt een naturalistische onderbouwing bij Nietzsches antihumanistische leer van de Übermensch, die zijns inziens de mens overwint en verdringt. Het is verleidelijk die internalistische beschrijving van de evolutietheorie ook in utilistische termen te interpreteren: het nut van dat mechanisme bestaat in de reproductie van informatie voor 'het leven' om te 'overleven'. Het is immers verleidelijk dit mechanisme zelf als een objectief gegeven op zichzelf te beschouwen en niet als louter benadering van wat er empirisch lijkt te gebeuren, terwijl evolutie slechts een begrip is waarmee wij biologische processen bespreekbaar proberen te maken. Het betekent een metafysische verschuiving wanneer wij in ontologische termen over dit mechanisme-an-sich als 'de evolutie' gaan spreken, alsof het zelf ook een bestaand ding is. De verleiding is dan om dit 'biologisch mechanisme' ('evolutie') externalistisch als eigenstandig fenomeen achter de biologische processen te beschouwen en te spreken van 'de evolutie' in plaats van 'evoluerende processen'..

\section{Religie als virus?}

Richard Dawkins heeft het idee van 'Universeel Darwinisme' gelanceerd waarbij hij claimt dat de logische structuur van de Darwiniaanse evolutie niet alleen toegepast kan worden op biologische verschijnselen, maar op alle evoluerende processen die aan specifieke vereisten voldoen. Die vereisten betreffen de genoemde punten van selectie, adaptatie, geschiktheid (fitness) en een analogie van de populatiestructuur. Het idee is nu dat ook de ontwikkelingen van culturen beantwoorden aan deze vereisten zodat ook culturen onderling en ook intern volgens een selectieproces 'darwinistisch' kunnen 'evolueren'. Draait de biologische evolutie om de variatie aan informatiedragers, de genen, dan moeten wij voor culturele processen een analogie zoeken. Met het gen als model postuleert Dawkins memen als bouwstenen van de ideeën die zich binnen een cultuur en in de confrontatie van culturen verspreiden (zie o.a. Dawkins 2004:278-279, 2006:222-234). Op die manier kan men de ontwikkeling van een idee dat zich doorzet ten koste van alternatieve ideeën, als een cumulatief evolutionair proces beschrijven: het 'doelloos' mechanisme verschijnt nu op een ander niveau opnieuw. Er bestaan wel verschillen: genen verspreiden zich bijvoorbeeld via seksuele voortplanting, maar ideeën door middel van schriftelijke en mondelinge communicatie en imitatie. Een culturele evolutie volgt dan analoge wetmatigheden als de biologische evolutie: ideeën zijn volgens Dawkins eveneens replicators, analoog aan de genen, want ook zij kunnen zichzelf kopiëren en op die manier 'informatie' bewaren. Dan verschijnt er een completer plaatje van de werkelijkheid: ergens in de biologische evolutie verschijnen wezens met 'bewustzijn' en taalvaardigheid en daar krijgt een nieuwe vorm van replicator zijn kans: 'de idee'. Het betekent evolutionair een 'Great Leap Forward'.

Om te overleven moet ook een idee zich reproduceren in zoveel mogelijk geschikte dragers zoals menselijke breinen,

9.'Evolutie' is evenals 'geschiedenis' een 'incompleet symbool': 'de geschiedenis' bestaat niet, maar wel de geschiedenis van iets concreets als de stad Amsterdam. 'De evolutie' bestaat niet, maar wel de evolutie van mensen. geschriften, digitale informatiedragers. Het idee gaat op zoek naar steeds meer verspreidingsmogelijkheden: zoals biologen over een 'genenpoel' spreken, zo introduceert Dawkins een 'memenpoel'. Hier neemt hij een paar logische wissels waarin hij een ontologische sprong maakt: van de metafoor 'meem' die te gebruiken lijkt als gen, stapt hij over op de gedachte dat deze metafoor ook 'reality depicting' is. Wat als een manier van spreken wordt geïntroduceerd, ontpopt zich vervolgens als een 'self-fulfilling prophecy'. Dat werkt bevreemdend in een context waar Darwin verscheen als de sloper van het essentialistisch bouwwerk in de biologie, daar voert Richard Dawkins het darwinistisch mechanisme in om een realistische ontologische claim te maken over de ontwikkelingen van culturen in plaats van een voorstel te doen om die ontwikkelingen bespreekbaar te maken. Hij voert via de achterdeur weer een soort 'essentialisme' in dat Darwin bij de voordeur eruit geworpen had. Dawkins denken verschijnt hier als een soort neo-fundamentalisme. ${ }^{10}$ Russells woorden blijkt hij te zijn vergeten.

De attractiviteit van de idee van memen past Dawkins ook toe op een specifiek cultureel aspect: religie. Religie benadert hij primair als een hypothese waarbij godsdienstig geloof functioneert als een overtuiging die betrekking heeft op een feitelijke stand van zaken in de ons omringende werkelijkheid. Op een dergelijke manier praten we over het bestaan van God als over dat van een natuurkundig object (Dawkins 2006:70-72): 'Either he exists or he doesn't. It is a scientific question.' We kunnen debatteren over de mate waarin deze hypothese min of meer waarschijnlijk is in vergelijking met alternatieve hypotheses. Naar zijn mening vormt een religie een systeem van kennisclaims die iets bovennatuurlijks veronderstellen, zonder dit laatste plausibel te maken. Het karakter van godsdienstig geloof als hypothese blijkt uit zijn bewering dat elke vorm van godsdienstig geloof volstrekt niet evident is, maar juist in tegenspraak met bepaalde wetenschappelijk vastgestelde feiten. Hij maakt hier zelfs een universele claim: dit geldt voor religieuze hypotheses van iedere andere, concurrerende, religie (Dawkins 2006:202).

Dawkins stelt dat godsdienst het gedrag van virus vertoont dat mensen op mentaal niveau besmet door zich van generatie op generatie te verspreiden als een cluster ideeën dat op zelfverspreiding is gericht, en zij beschikt daarvoor over een strategie om haar ideeën effectief te laten reproduceren en operabel te maken. Belangrijk lijkt mij hier op te merken dat Dawkins stilzwijgend de veronderstelling introduceert dat wij over ideeën als actieve replicatoren moeten spreken, analoog aan zijn idee van een actief beleid van de genen: hij hanteert hier personifiërende taal voor genen en memen die zelf willen overleven. Niet de organismen geven genen door, maar genen bedienen zich van organismen voor reproductie. Zo geven mensen geen memen door in hun communicatie met anderen, het werkt juist andersom: bepaalde succesvolle memen verspreiden zich via mensen. Hij lijkt een wetenschappelijke religietheorie aan te bieden,

10.Rosenberg en McShea (2008:217) wijzen erop dat een 'meem' wel een suggestieve metafoor oplevert, maar daarmee nog geen algemene theorie voor een culturele evolutie. 
maar Dawkins verwerpt de hypothese van het bestaan van God als gebaseerd op inadequate bovennatuurlijke gronden, terwijl hijzelf het bestaan van memen postuleert die hij bovendien een succesvolle strategie toeschrijft. Welke empirische argumenten kan hij aandragen voor een werkelijk doelbewust optreden van memen? Dat wij met een 'meem' (als een na te bootsen idee) een nuttige metafoor hebben om verspreiding van ideeën bespreekbaar te maken zodat wij attent zijn op ontwikkelingen ervan in of tussen culturele contexten, rechtvaardigt nog niet om vervolgens een vergaande ontologische claim over de memen te maken. Wie een metafoor echter als 'reality depicting' gaat beschouwen, maakt van zulke replicatoren als genen en memen ook nog doelbewuste actoren, terwijl het darwinistisch mechanisme juist een blind en doelloos proces als de biologische evolutie plausibel probeert te maken. ${ }^{11}$ Dawkins schroomt duidelijk niet om als atheïst zich hier van animistische mythen te bedienen waarin gepersonifieerde genen en memen - als betrof het elfjes - doelbewust handelend optreden. Hij spreekt over clusters van memen, 'meemplexen' geheten ('meme' + 'complexes') die in coöperatief verband effectiever kunnen opereren en zich verbreiden dan elk meem individueel. Met deze coöperatie is een nieuw onderdeel aan zijn memenmythe toegevoegd. ${ }^{12}$

Dawkins hanteert zijn memenmythologie voor zijn weinig genereuze voorstel om religie als gevaarlijk virus te bespreken dat zich probeert voort te planten via volgende generaties die in de opvoeding een en dezelfde godsdienst krijgen opgedrongen zonder zelf vrijwillig een keus te kunnen maken. Ook hier hanteert hij een metafoor, nu als waarschuwing om daarmee aan te geven welke houding in het algemeen tegenover godsdienst gepast is. In godsdienst worden we immers volgens hem geconfronteerd met irrationele leerstellingen die op gespannen voet met de wetenschappelijke bevindingen staan. Niet mensen bedienen zich van godsdienstige ideeën, maar juist religie profiteert van gelovigen met hun gemeenschapsbesef. Het is haar strategie op deze manier zich te verbreiden: religie is een mooi voorbeeld om de coöperatieve werking van een meemplex als indoctrinatie te beschrijven. Dit meemplex met eschatologische begrippen als 'hiernamaals', 'hel' en 'hemel' handhaaft zich door gelovigen in de greep te houden met een duidelijke presentatie van tegengestelde alternatieven als toekomstverwachting: loon versus straf overeenkomstig hun gedrag. Het is een religieuze strategie om als meemplex de verbreidingskansen te vergroten. Op een dergelijke manier kunnen we de opkomst, verspreiding en teruggang van godsdiensten begrijpen: de krachtigste replicatoren zetten zich door.

Het probleem van Dawkins' benadering van godsdienst betreft zijn onkritische omgang met zijn eigen voorstellen. Zijn voorstel om evolutionaire gedachtegangen te gebruiken om ook ontwikkelingen in en tussen religies bespreekbaar te

11. Hier lijkt de claim van Darwin dat toevalsprocessen juist doelloos tot bijzondere organismen kunnen leiden opgegeven. Is dit voorstel van Dawkins wel een verfijning van het evolutionaire denken of juist een terugval?

12.Zijn betoog verliest zich hier in 'mythologiseren' zonder enig besef van de betekenis van mythen in het leven van gelovigen (Dawkins 2006:228-231). maken combineert hij met een tweede voorstel. Dit betreft zijn atheïstische agenda om godsdienst als een complex van ideeën te bespreken dat erop gericht is zichzelf als virus te verspreiden. Hij bedient zich hier van doorzichtige retoriek en geeft niet kritisch zijn criteria aan hoe hij deze hypothese denkt te toetsen. Evenmin stelt hij zijn eigen begrip van religie als complex van overtuigingen die refereren aan een bovennatuurlijke werkelijkheid ter discussie, maar hanteert zijn begrip als een universeel aanvaarde voorstelling van zaken. Om welke reden hij dit doet, legt hij niet uit. Voor een wetenschapper die empirisch onderzoek als graadmeter voor de juistheid en plausibiliteit van zijn overtuigingen beschouwt, doet het wonderlijk aan wanneer hij zich niet bekommert om de vraag in hoeverre gelovigen zijn epistemische voorstelling van religie eigenlijk wel kunnen herkennen. Veel fundamentalisten dieDawkins' evolutionaire benadering van religie verafschuwen en verwerpen, delen merkwaardig genoeg zijn epistemische opvatting dat religieuze opvattingen de rol van een verklaring voor het bestaan van de ons omringende werkelijkheid vervullen. Zijn idee van de religieuze mens als viraal besmet individu is vanuit een Cartesiaans ego gedacht, maar hij vraagt niet hoe deze gelovigen de hun toegeschreven besmetting zelf beleven. Een alternatief voor zijn diagnose overweegt Dawkins niet eens, namelijk dat gelovigen hun godsdienst beleven als heroriëntatie op hun eigen leven in zijn sociale netwerken en op de zin ervan, op hun naaste medemensen en op de hen omringende wereld.

\section{Religie als toestand van het brein?}

Terwijl Dawkins religie benadert als een complex van overtuigingen en verwachtingen waarmee mensen van buitenaf zijn besmet, beschouwen andere materialistische onderzoekers godsdienst als een cluster mentale activiteiten die juist interne hersenprocessen weerspiegelen. Volgens een strikt biologisch determinisme binnen de psychologie zijn bewustzijn, emoties, gedachten of intenties niet meer dan secundaire bijverschijnselen van fysieke hersenprocessen waarop mensen zelf weinig of geen invloed kunnen uitoefenen. Hier richt het perspectief zich op de binnenzijde van het Cartesiaans ego. Deze visie negeert de idee dat we dergelijke verschijnselen ook sociaalpsychologisch kunnen beschouwen. Men debatteert over de vraag of de moraal een evolutionaire oorsprong heeft en eerder vanuit de biologie dan vanuit de filosofie besproken zou moeten worden. Edward O. Wilson betoogt dat analoog aan de evolutie van het brein ook ethische, esthetische en religieuze opvattingen evolutionair ontstaan zijn en dus uit de genetische voorgeschiedenis verklaarbaar worden (Wilson 1978:1-2).${ }^{13}$ Het is nu een kleine stap van religie als sociaal of tribaal fenomeen naar religie opgevat als louter fysiologisch fenomeen, dat mechanisch kopieerbaar is. Die stap maakt Michael Persinger.

13.Zie ook Wilson 1998:119-120, 261-264. Hij betoogt: 'The power of organized religions is based upon their contribution to social order and personal security, not to the search for truth. The goal of religions is submission to the will and common good of the tribe' (Wilson 2012: loc. 3932). Daartegenover wijst John Bowker op de riten waarmee hersenen processen zoals associatief leren en symbolische cognitie me elkaar verbinden om te reageren op de omgeving. We leven ingebed in de rationele wereld van symbolen en tegelijkertijd in de emotionele beleving van die symbolen. Deze notie van 'gelijktijdigheid' van rede en emotie behoedt ons om emotie tot rede te reduceren (Bowker 2005:108-118, spec. 113). 
Persinger heeft op het terrein van de neuropsychologie allerlei elektromagnetische experimenten uitgevoerd die bij proefpersonen in de slaapkwab kunstmatig religieus beleefde verschijnselen teweegbrengen. Hij gebruikt daarvoor een helm met elektromagneten aan de zijkant die in The Independent zelfs als 'Dr. Persinger's God Machine' is bestempeld. Mij gaat het in dit verband niet om technische of methodologische details van deze experimenten (zie daarover bijv. Watts 2002:82-83; Runehov 2007:99-135), maar om een godsdienstfilosofische beoordeling van de veronderstelling van deze 'Godmachine'. Men kan blijkbaar een virtuele wereld bij proefpersonen oproepen waarbij een 'gebrek' aan religieuze beleving ondervangen wordt door een apparaat dat werkt als was het een geloofsprothese voor 'mensen met geloofshandicap'.

Persinger stelt een samenhang te kunnen aantonen tussen beelden en indrukken van licht en geluid bij korte epileptische aanvallen in de slaapkwab en bijzondere religieuze ervaringen. Aspecten van korte epileptische aanvallen worden wel als een religieuze Godservaring geïnterpreteerd met behulp van een Godsconcept dat volgens materialistische neurologen in de linkerhelft van het brein met de regio van de slaapkwab 'geassocieerd' is. Dat Godservaringen zich voordoen is volgens hem het gevolg van de specifieke vorm van de slaapkwab zonder welke een dergelijke ervaring onmogelijk is (Persinger 1987:16, 111, 1993:915-930, 2006:1079-1096). Ontologisch identificeert hij dus een religieuze beleving met een lokale verandering in hersenactiviteit, wat op een a priori reductie van die beleving tot hersenactiviteit neerkomt. Met zijn experimenten wil hij een neuro-elektrische basis van mystieke ervaringen en bekeringen aantonen om een behandeling van religieuze depressies te ontwikkelen. Uiteindelijk zijn termen als 'God' of 'eeuwigheid' slechts woorden die naar meetbare hersenactiviteiten verwijzen. ${ }^{14}$ Het lijkt een reductionistische miskenning door geloofsbeleving equivalent te stellen aan enkel een epileptische toestand van het brein. Deze technische reconstructie van de individuele homo religiosus negeert de situering van de gelovige binnen een geloofsgemeenschap en de beleving daarvan, inclusief haar praktijken en haar conceptueel kader. Deze mens wordt primair als los individu bekeken, geïsoleerd van de geloofsgemeenschap. ${ }^{15}$

Dit mensbeeld veronderstelt een naturalistisch postulaat dat alleen de natuurwetenschappelijke beschrijving van de werkelijkheid dwingende betekenis heeft. Een dergelijk monistisch werkelijkheidsbeeld biedt de ultieme betekenis van alles. Dit naturalisme poneert daarmee het metafysisch standpunt dat de werkelijkheid uiteindelijk alleen uit materie en materiële processen bestaat. Zo betoogt ook Mikael Stenmark tegenover het naturalistisch gezichtspunt van Edward Wilson: 'Naturalism is a necessary philosophical presupposition of science ... and therefore ... [the] claim that science

14.Zie Persinger (1987:84): “God Experiences cannot be verified and extended. They are a part of the machine, ...'

15.Zo bekritiseert de wetenschapsfilosofe Donna Haraway de imaginaire cyborg als voorbeeld van het technologisch denken dat dingen-op-zich beschouwt, afgezien van enige sociale relationele (!) inbedding (Haraway 1991:22, 154). can explain religion as a wholly material phenomenon is a nonscientific claim' ... (Stenmark 2001:95).

Een dergelijke claim is dus juist op een metafysisch uitgangspunt gebaseerd, aldus Stenmark. Daarentegen heeft godsdienstig geloof als actief beleven van de wereld, als coram Deo, echter het karakter van een contingente activiteit. Binnen een naturalistisch wereldbeeld is die handeling illusoir, omdat religieuze activiteiten als bewuste praktijken binnen een naturalistisch determinisme niet gerechtvaardigd kunnen worden. Daarmee staan we voor het probleem: maken mensen werkelijk een keuze door bewust een geloofstraditie te volgen of zijn zij daartoe biologisch gedetermineerd?

Materialisten menen dat mentale activiteiten, dus ook religieuze, geheel door biologische factoren in het menselijk brein worden bepaald. Edward Wilson beweert dat de emoties die religieuze vervoering begeleiden duidelijk van neurologische aard zijn en daarom maken die emoties een transcendent verstaan van godsdienst overbodig. Krasser formuleert Daniel Dennett, een overtuigd materialist:

The idea of mind as distinct ... from the brain, composed not of ordinary matter, but of some other, special kind of stuff, is dualism, and it is deservedly in disrepute today ... The prevailing wisdom, variously expressed and argued for, is materialism: there is only one sort of stuff, namely matter - the physical stuff of physics, chemistry, and physiology - and the mind is somehow nothing but a physical phenomenon. In short, the mind is the brain. (Dennett 1991:33; zie ook Wilson 1998:258-266)

Hier identificeert Dennett de menselijke geest met het brein door een 'nothing buttery' argument dat berust op het postulaat dat het universum alleen uit materie bestaat zodat alle activiteit enkel materieel kan zijn. Dit is een petitio principii. Het brein functioneert inderdaad als biologisch orgaan overeenkomstig fysiologische wetten die biologisch noodzakelijke processen beschrijven. De identificatie van geest en brein is echter een tweede stap die onze mentale overwegingen bij onze handelingen gelijkstelt aan dergelijke fysiologische processen. Binnen de natuurwetenschappen is deze identificatie methodologisch vanzelfsprekend, maar Dennett claimt dat er geen terrein buiten dat van de natuurwetenschappen bestaat. Dit is echter in feite een metafysische claim, die niet op enige fysische grond is te baseren, zoals dus ook Stenmark betoogt tegenover Edward Wilson. Kortom: dit is een categoriefout! Dennett, Dawkins en ook Wilson beschouwen de werkelijkheid vanuit een extern gezichtspunt en claimen van daaruit dat er enkel en alleen materiële processen binnen deze werkelijkheid plaatsvinden. Daarmee doen zij over het geheel van de werkelijkheid een objectieve en universele uitspraak, terwijl zij, zelf als deel van die werkelijkheid, ergens binnen die werkelijkheid hun eigen tijdruimtelijke plaats innemen. Daarmee overstijgen zij deze concrete plaats en doen vanuit een Archimedisch perspectief waarin de werkelijkheid voor hen als extern 'object' verschijnt, uitspraken over die werkelijkheid als geheel inclusief henzelf met hun eigen locale perspectief; anders gezegd, zij spreken alsof zij een God's Eye point of view kunnen innemen (zie Putnam 1981:49-60; Van den Brom 2004:282). Aan een dergelijk perspectief kunnen wij met een fysisch begrip als 
materie geen betekenis geven, want het heeft geen materiële plek in de materiële wereld en kan die ook logischerwijs niet hebben: een dergelijk Archimedisch perspectief is niet te vermaterialiseren. Dennett, Dawkins en Wilson spreken, gebruikmakend van immanente begrippen zoals 'materie' en 'natuurwetten' die binnen onze werkelijkheid betekenis hebben, over die werkelijkheid als geheel. Wij leven in een wereld die door natuurwetten is bepaald. Waarom gelden deze wetten daarin? Als wij antwoorden dat zij gelden omdat wij in een materiële wereld leven, dan hanteren wij een cirkelredenering, want 'materieel' betekent zoveel als 'bepaald door natuurwetten'. Het lijkt er niet op dat Dennett, Dawkins of Wilson hier een probleem zien.

Voorzichtiger formuleren Andrew Newberg en Eugene d'Aquili dat naturalistisch gesproken het limbisch systeem rond de verbinding van de hersenhelften ertoe bijdraagt dat wij ons met religieuze activiteiten bezig moeten houden. ${ }^{16}$ Binnen dit naturalistisch perspectief verdedigen zij godsdienst door God als functie binnen de hersenen te lokaliseren. Vanwege hun vele publicaties over de neurologische wortels van de godsdienst heten zij wel de pioniers van de neurotheologie. Zij stellen dat het Godsbegrip nooit zal verdwijnen omdat de gedachte door diverse breintoestanden wordt geproduceerd, zodat 'God' in ons hoofd is gelokaliseerd, hoewel hij ook onafhankelijk gedacht kan worden. Wanneer ons brein als biologisch orgaan werkt, dan is een dergelijk Godsbegrip een noodzakelijk product dat met ons fysieke bestaan gegeven is. Zij betogen niet dat geloof illusie is omdat 'God' nu in ons brein gelokaliseerd is, maar beweren wel:

If God exists, for example, and if He appeared to you in some incarnation, you would have no way of experiencing His presence, except as part of a neurologically generated rendition of reality ... Neurology makes it clear: There's no other way for God to get in your head except through the brain's neural pathways. (Newberg \& d'Aquili 2001:37) ${ }^{17}$

Hier worden God en de Godservaring neurologisch beperkingen opgelegd zonder dat er een theologische conceptuele analyse wordt geboden van de rol die God en het Godsbegrip in het leven van gelovigen spelen. Newberg en d'Aquili leggen hier God metafysisch beperkingen op door zijn eventuele creatieve handelen te binden aan wat zij zelf als enige toegang voor religieuze ervaringen binnenwereldlijk mogelijk achten: enkel via zenuwbanen van de hersenen. $\mathrm{Zij}$ formuleren daarmee een antropologische hypothese over een aanknopingspunt in ons brein voor het Godsgeloof.

\section{Religie als groepsvorming}

Terwijl Dawkins met zijn medestanders religie interpreteren vanuit het individu dat mentaal in beslag wordt genomen door of besmet met een religiemeemplex, verdedigt David Sloan Wilson een ander gezichtspunt op religie. Hij wijst erop dat Dawkins idee van religie als replicator ons op het verkeerde been zet door gelovigen als geïsoleerde

16.Evolutionair omvat het limbisch systeem primitieve organen als de hypothalamus, de amygdala en de hippocampus en verbindt emotionele prikkels met reflecties in de neocortex en leidt tot zelfbesef.

17.Dit is werkelijk een vorm van sciëntisme: de wetenschap bepaalt wat voor God mogelijk is. Dat een dergelijke claim absurd is, betoogt Smedes (2004:173-206). individuen te bekijken en de betekenis van de groep te negeren. Hijzelf beschouwt religie als het resultaat van groepsselectie: natuurlijke selectie speelt niet alleen op het niveau van individuele organismen, maar ook op dat van groepen. Groepen van coöpererende individuen zijn vaak succesvoller dan groepen van op zichzelf opererende individuen. Hij constateert dat de biologische selectiedruk resulteert in groepsvorming van samenwerkende individuen die zich als nieuwe eenheid manifesteren waarbij de groep nu zelf als één organisme functioneert. ${ }^{18}$ Dit herkennen we in de theologie wel als iets analoog aan de notie van de 'corporate personality', maar deze voorstelling attendeert ons ook op een verschil: de mogelijkheid van intentioneel handelen. David Wilson ziet religie ontstaan waar deze voor de groep als groep voordeel verschaft en volgt dus niet de mythologie van Dawkins van memen en meemplexen. Hij vraagt zich af of vanuit een evolutionair perspectief ook religie als sociaal bindmiddel (geen virus) is te begrijpen, dat werkt als 'culturele groepsselectie' en leidt tot wederzijds vertrouwen en support, tot coöperatie en gemeenschapszin, naar analogie van bijenvolken en mierenstaten (Wilson 2007:237-238). Volgens David Wilson maakt een godsdienst zijn participanten geschikt voor hun locale omgeving om coöperatief te realiseren wat zij individueel niet kunnen bereiken, ook niet samen zonder godsdienst. Hij noemt zijn visie op religie 'the group-level adaptation hypothesis', omdat religie 'primair' voordeel in deze wereld verschaft en niet in een hiernamaals.

David Wilson gebruikt het ontstaan van Calvijns variant van het protestantisme om zijn evolutionair denkschema als effectief te illustreren hoe een gemeenschap als Genève met, respectievelijk zonder, de nieuwe godsdienst functioneerde. Calvijns variant beslechtte het probleem van groepsversplintering in de Geneefse gemeenschap door deze om te smeden tot een morele gemeenschap met de handhaving van tucht ter voorkoming van corruptie: dit creëerde een sociale infrastructuur voor de burgers van Genève zodat de stad als een eenheid functioneerde, 'als een bijenvolk' (Wilson 2007:242-245). We kunnen ons echter wel afvragen of dit fenomeen 'groepsselectie' nu de kip en de religie het ei is. Omgekeerd kunnen we ons ook indenken dat een levende religie met haar praktijken weliswaar appelleert aan een mogelijk reeds bestaand groepsgevoel, maar dat wij dit proces vanuit een ander, dat is internalistisch perspectief kunnen begrijpen. Waarom zouden dergelijke processen niet onderling op elkaar afgestemd kunnen zijn? Dawkins, Dennett en de beide Wilsons bekijken religieuze processen eendimensionaal: het een (religie) volgt uit het ander (groepsselectie), terwijl de mogelijkheid van processen die gelijktijdig (zoals Bowker 2005:113) of complementair plaatsvinden eigenlijk niet aan de orde komt. In de gemeenschap waaraan Calvijns activiteiten bijdroegen speelt ook geloof en bekering een belangrijke rol. Sociobiologen bekijken (vanuit een externalistisch perspectief) het voordeel

18.'Crossing the threshold from groups of organisms to groups as organisms is not easy' (Wilson 2007:145). Wilson wijst erop dat men in de evolutie van de insecten deze sprong naar een sociale groep slechts 15 maal heeft opgemerkt, maar dat hij deze sprong naar een sociale groep slechts 15 maal heeft opgemerkt, maar dat hij
wel effectief is gebleken, want deze sociale insecten staan wel voor de helft van de biomassa der insecten. 
dat religie aan de sociale samenhang van een groepsverband verschaft. Hoewel ik het sociaal kapitaal van het christelijk geloof zeker niet ontken ('de gemeenschap der heiligen'), wil ik erop wijzen dat christelijk geloof zich manifesteert in gelovigen, die zich immers omringen met praktijken binnen de geloofsgemeenschap als ook daarbuiten. ${ }^{19}$ Daarmee dragen deze praktijken aan de sociale cohesie bewust bij, maar primair laten zij de betekenis van het christelijk geloof zien zoals ook het geloof de betekenis van de praktijken toont. Deze wisselwerking heeft te maken met het gegeven dat gelovigen personen zijn die intentioneel handelen en niet enkel instinctief of impulsief, waarin zij zich van dieren onderscheiden.

Voor onze gedragingen kunnen we redenen of motieven opgeven waarmee wij onze activiteiten rechtvaardigen, wanneer anderen ons vragen waarom wij voor medemensen behulpzaam zijn. Christenen kunnen deze activiteiten motiveren door zich bijvoorbeeld te beroepen op de gulden regel van Matteüs 7:12 om uiting aan hun betrokkenheid bij de dienst aan de Heer te geven wanneer zij medemensen daadwerkelijk te hulp komen: 'De Heer doet ons met andere ogen naar medemensen kijken: niet als concurrenten of tegenstanders.' In hoeverre deze gulden regel voor elk mens acceptabel of verwerpelijk is of moet zijn, kunnen wij onderling bediscussiëren. Dergelijke motieven vormen niet de oorzaken van ons gedrag; er bestaat geen causaal verband tussen ons motief en onze hulpvaardigheid, zodat deze bereidwilligheid niet een onvermijdelijk gevolg is. Anders gezegd: de gulden regel formuleert geen natuurlijk mechanisme tussen onze motieven en daden. Daarom kunnen wij erover discussiëren of de gulden regel moreel goed of slecht is, maar ook of deze regel al onze medeschepselen betreft, dus ook dieren. Wij blameren een wolf niet omdat hij geiten verslindt, want hij kan zijn instinct niet veranderen, terwijl mensen zich wel tegen hun impulsieve handelingen kunnen verzetten, maar ook hun motieven veranderen ofwel zich bekeren. Nu kent men in de biologie een debat over onbaatzuchtig gedrag (altruïsme) waarbij de vraag aan de orde is in hoeverre onbaatzuchtig gedrag en coöperatie uiteindelijk op 'genetisch egoïsme' is gebaseerd, als betrof het weloverwogen eigenbelang (Wilson, E.O., 2012: loc. 312; Wilson, D.S., 2007:273-274, 306-307).

Mensen worden 'eusociaal' of 'prosociaal'20 door de sociobiologen genoemd omdat zij het in zich hebben om zich altruïstisch te gedragen als onderdeel van een onderlinge werkverdeling, vergelijkbaar met mieren, bijen en termieten. Er bestaat evenwel een groot verschil tussen mensen en sociale insecten: mensen hebben cultuur, taal en hoge intelligentie, maar gaan ook verbintenissen met elkaar aan, individueel als ook in groepsverband. Mensen erkennen

19.Calvijn ziet geloof en leven in heiligheid onlosmakelijk met elkaar verbonden als basisprincipe voor de heilsleer, want heiliging gaat niet zozeer over 'goede werken', maar over de unio cum Christo (Partee 2008:215)

20.David S. Wilson verkiest het woord 'prosociaal' om 'altruïstisch' te vermijden dat volgens hem ook noodzakelijke zelfopoffering zou kunnen impliceren en vreemd is volgens hem ook noodzakelljke zelfopoffering zou kunnen impliceren en vreemd is en vraagt niet naar het praktisch gebruik: 'altruism [is] benefiting others at the expense of self (vgl. Wilson 2007:306 en 272-273). Religieuze teksten geven expense of self (vgl. Wilson 2007:306 en 272-273). Religieuze teksten geven is mijn naaste?' beantwoordt met een verhaal (Luk 10:25-37). eigendom en persoonlijke status binnen een groepsverband en de onderlinge omgang is gebaseerd op een strategische mengeling van welberekend altruïsme, samenwerking, concurrentie en dominantie, inclusief ontrouw en bedrog. Daarbij moest de menselijke soort over inlevingsvermogen beschikken om emoties en intenties van anderen in te schatten om een sociale strategie voor persoonlijke interacties te organiseren en beleidsplannen in verband met eventuele consequenties uit te denken. Daaruit groeide volgens Edward Wilson de menselijke omstandigheid die door twee impulsen werd bepaald: soms eigenbelang en soms altruïsme. Hij stelt dat alle normale mensen tot echt altruïsme geneigd zijn, maar zijn onder de dieren uniek in de mate waarin zij dit betonen. Het blijkt dat door 'authentiek altruïsme' de kracht en de concurrentiepositie van de groep groeit. Onder gelovigen is liefdadigheid als altruïsme gericht op medegelovigen maar jegens buitenstaanders enkel om hen te bekeren ('zieltjes winnen'). Religie dient uiteindelijk de sociale orde en individuele veiligheid en vergt onderwerping aan het algemeen belang van het groepsverband van de stam en is niet gebaseerd op onderzoek naar de waarheid (Wilson 2012: loc. 3781-3784, 3801, 3929-3938). Religie verdwijnt niet door rationele passie voor moraliteit, maar onwetendheid bij gelovigen verdwijnt door de wetenschappelijke overtuigingskracht dat religie een evolutionair product blijkt te zijn: rationaliteit gaat ten koste van 'belachelijke' scheppingsmythen. Op zoek naar een binnenwereldlijke redding van onze biosfeer als een seculiere eschatologie droomt Edward Wilson van een 'nieuwe Verlichting' die de mensheid naar een nieuw paradijs voert (Wilson 2012: loc. 4408-4450).

Dat menselijke geloofsgemeenschappen gelijkenis vertonen met sociale insecten, zoals bij mierenstaten en bijenvolken in hun sociale zorggedrag, hoeven we niet te ontkennen. Het levert de religieuze taal ook metaforen (Spr 6:6; 30:25). De verklaring van godsdienst als niets anders dan een vorm van groepsadaptatie suggereert dat het gedrag van gelovigen hetzelfde is als van sociale insecten. Daarmee kijken sociobiologen vanuit een extern perspectief naar de twee groepen - gelovigen en mieren - waarbij zij uiterlijk eenzelfde fenomeen constateren op grond waarvan zij menen te mogen concluderen dat gelovigen en insecten hetzelfde doen. Dit lijkt mij een behavioristische drogreden: op grond van uiterlijk waargenomen gedrag vaststellen wat gelovigen daar doen hetzelfde is als gedrag van mieren. Zoals boven opgemerkt handelen mensen intentioneel en geven met hun motieven of redenen aan wat zij in feite doen. Buitenstaanders kunnen zich wel motieven voor dat gedrag van gelovigen indenken met hun inbeeldingsvermogen, maar uiteindelijk bepalen de gelovigen zelf wat zij doen, en niet de wetenschappelijke waarnemer. Brümmer bespreekt een voorbeeld van twee ontwikkelingswerkers die beiden een vrachtwagen met voedsel naar een vluchtelingenkamp rijden: de ene bestuurder werkt aan de bevordering van de maoïstische heilstaat terwijl de ander werkt binnen het kader van het Koninkrijk van God (Brümmer 2008:126-127). Al nemen wij analoog gedrag waar, wij kunnen op grond daarvan niet stellen wat voor handelingen zij verrichten. 
Wij kunnen niet stellen dat godsdienstig gedrag niets anders is dan groepsadaptatie, omdat gelovigen en mieren verschillende handelingen verrichten. Gelovigen hebben niet alleen instincten en impulsen (verlangens), maar hebben ook motieven waarmee hun gedrag zijn eigen betekenis krijgt. Zij dragen verantwoording voor hun daden en kunnen om rekenschap daarvan gevraagd worden met welke motieven zij zich rechtvaardigen. Daarin verschillen zij in elk geval van dieren: altruïsme bij mensen is niet instinctief, maar zij hebben een betekenisgevend verhaal voor altruïsme.

\section{Theologische antropologie als kritiek}

In een theologische antropologie wordt geen wetenschappelijke theorie over de mens geboden, maar een oriëntatie gegeven hoe mensen zich tot hun leefwereld kunnen verhouden, daarin spreken en handelen. Daarbij zijn niet alleen inzichten uit de humane biologie belangrijk, maar ook gezichtspunten van het christelijk geloof: waarop is ons leven georiënteerd, hoe gaan wij met elkaar om, hoe geven we uiting aan wat mens-zijn is en aan wat de zin van ons leven inhoudt? In dit verband betekent complementariteit dat een theologische antropologie zich ervan rekenschap geeft hoe zij mensen enerzijds biologisch en anderzijds geestelijk als geschapen (geschonken) eenheid beschouwt. Daarvoor kunnen lijfelijke en mentale begrippen tegelijkertijd adequaat gebruikt worden. Mensen zijn in gemeenschap geschapen en bevinden zich in netwerken van sociale relaties. Als we de geloofsbeleving van mensen enkel neuraal - dat is biologisch - interpreteren, dan kunnen we bij mensen (individueel, even geabstraheerd van hun context) wel analoge neurale gewaarwordingen simuleren, maar dergelijke ervaringen betekenen nog niet hetzelfde als geloofsbeleving. Zowel Persinger als Newberg en d'Aquili zien geloof in God als een toestand-op-zich ergens in een individueel brein en verdisconteren niet dat het hier een mens betreft die is ingebed in een hele godsdienstige praktijk met taal, rituelen en beleving. Volgens Persinger correspondeert met dit geloof in God geen externe referent. Newberg en d'Aquili, zijnde agnost, menen dat met het concept 'God' zelf in elk geval geen andere empirische referent correspondeert dan de God spot in het brein. ${ }^{21}$ Zo kijken zij fysiologisch naar godsdienstig geloof als een lokale toestand in het brein en constateren dat het brein epistemologisch uitspraken voor waar aanvaardt om die met feitelijke standen van zaken te willen beargumenteren. Die argumentatie moet dan leiden tot een of andere feitelijke claim omtrent een godsdienstig object: bijvoorbeeld God.

Newberg en d'Aquili behandelen hier godsdienstig geloof op twee niveaus: ten eerste als een fysiologische toestand in het brein en ten tweede als een daaraan gerelateerde epistemische claim die instemt met een empirische hypothese

21.Zou God eventueel bestaan, dan moet volgens hen deze God zich wel van de Godspot als een aanknopingspunt bedienen om zich bekend te maken (Newberg \& Godspot als 'Aquili 2001.37). God als concept kan alleen in onze geest bestaan in de visie van Newberg en dAquill. Dit zegt echter NIETS over de ontische status van degene die wij met dit concept ter sprake brengen, evenmin over de relatie van God tot ons als gelovigen: God is namelijk niet God-op-zich, maar altijd Deus-pro-nobis! over Gods bestaan. Zij besteden echter hoegenaamd geen aandacht aan de geloofspraktijk als geheel. Neurologisch kunnen zij echter niet constateren of die fysieke toestand van een plek in het brein zijn oorsprong vindt in en correspondeert met een 'extern object' als God tegenover ons. Zo bezien betekent godsdienstig geloof voor hen enkel een set proposities die materieel een lokale toestand in het brein beschrijft, terwijl semantisch voor hen geloof een misplaatste religieuze hypothese omtrent een vermeend object God voorstelt. Voor Persinger geldt dat 'God Experiences cannot be verified and extended. They are a part of the machine.' De religieuze taal creëert zijns inziens haar eigen entiteiten, waarbij hij zich over religieuze praktijken respectloos uitlaat en hun inbedding in sociale netwerken irrelevant acht: "God" is simply "dog" spelled backwards' (Persinger 1987:84). Voor deze logische positivist is het woord 'God' betekenisloos, omdat het niet descriptief naar een empirisch vaststelbare entiteit verwijst. Daarmee negeert Persinger de rol van godsdienstige taal binnen het complexe netwerk van de christelijke geloofsgemeenschap, waarbij het woord 'God' niet enkel een drieletterteken is. Het heeft daarentegen juist een evocatieve betekenis in de levensvorm waarin gelovigen leven en hun betrokkenheid op Hem uitdrukken voor wiens aangezicht zij hun leven hier en nu beleven, zonder diens plaats ruimtelijk aan te hoeven wijzen: God geldt overal. Geloofstaal is niet descriptief, maar heeft juist in de geloofspraktijk een zelfverbindende (relationele) functie waarmee gelovigen zich tot bepaald gedrag, gezindheid en attitude verplichten.

Godsdienstig geloof als fysiologische toestandsbeschrijving levert informatie op die technologisch mogelijk in de homo techno-sapiens inplantbaar is. Door geloof als informatie op fysiologisch en epistemologisch niveau te benaderen, behandelen deze neuro-wetenschappers slechts één kant van het geloof, die de klassieke dogmatiek de fides quae creditur noemt. Diefides quae creditur vertoont een hypothese structuur, bijvoorbeeld: 'ik geloof dat God de wereld geschapen heeft.' Wie louter aandacht voor de neurologie heeft, laat echter buiten beschouwing dat neurale gewaarwordingen niet achteraf pas religieus worden geïnterpreteerd. Gelovigen beleven deze gelijktijdig in een conceptueel geloofskader, zoals bijvoorbeeld ook Hildegard von Bingen en Dostojewski mystieke ervaringen bij epileptische aanvallen hadden (zie Bowker 2005:113). Theologisch gezegd: neurale gewaarwordingen verschijnen voor gelovigen tegelijkertijd met de attitude en gezindheid die allerlei emoties als vreugde, vertrouwen, hoop, overgave, liefde, dankbaarheid of bezorgdheid, maar ook twijfel en aanvechting, omvat. Deze attitude heet dogmatisch fides qua creditur. Dit duidt op een complex van relationele termen die intentioneel zijn, zoals 'vreugde om het bestaan', 'vertrouwen op Gods zorg', 'overgave aan de weg van het leven in geloof, liefde tot de naaste', 'dankbaarheid voor de geloofsgemeenschap', 'hoop op een zinvolle toekomst met God', enzovoort. Anders dan voor genoemde neuro-wetenschappers heeft 'God' in de fides qua een relationele betekenis: 'mijn God', 'God voor ons', 'God van de geloofsgemeenschap', 'de God en Vader van Jezus Christus'. 
God ter sprake brengen betekent jezelf met een complex van religieuze taalspelen binnen een hele levensvorm ter sprake brengen vice versa! Spreken we van God, dan spreken we over ons leven met God en over de gewetensvolle vormgeving daarvan binnen de levensvorm waarvan wij deel uitmaken. Geweten is geen ding, geen orgaan in het brein, maar duidt een beleven van praktijken aan waarin wij de aard en kwaliteit van ons gelovig gedrag wegen en overwegen ten overstaan van het morele kader waarin God Drie-enig de ultieme plaats inneemt. De informatie die de fides quae weergeeft, kan als set van algemene gegevens mogelijk 'in iets' worden vastgelegd, maar kan per definitie de existentiële fides qua niet omvatten. Daarentegen is de 'mens' bij Dawkins, Newberg en d'Aquili, en Persinger gereduceerd tot een non-person zonder relaties, waarbij de intentionele fides qua niet ter sprake kan komen omdat deze fides qua in hun denken een categoriefout is. Gaat het immers hier nog over personen? Brengen wij bij religie David S. Wilsons idee van groepsadaptatie ter sprake, dan moeten wij niet primair denken wat nuttig voor de geloofsgemeenschap is, maar beseffen dat voor haar het begrip 'gemeenschap' ruimer ingevuld wordt met gemeenschappelijk leven ten overstaan van de God en Vader van Jezus Christus. Deze groepsbeleving van de christelijke geloofsgemeenschap heeft ook een eenduidige naam waardoor deze beleving haar oriëntatie krijgt: deze gemeenschap beleeft zich als lichaam van Christus en zij weet zich op Christus als haar hoofd betrokken. Medegelovigen zijn daarmee gezien als leden van het lichaam van Christus en onbaatzuchtig handelen ten opzichte van medegelovigen heeft dan voor gelovigen de intentie om zorg te dragen voor het zijn en welzijn van het lichaam van Christus. Onbaatzuchtig handelen jegens niet-gelovige medemensen heeft niet verkapt de intentie om zieltjes voor de kerk te winnen, maar dient als visitekaartje van de Heer, om hem als het hoofd van het lichaam te representeren. In de kerk als gemeenschap is de Heer in wereld present (Van den Brom 2012). Met de gelijkenis van de Barmhartige Samaritaan maakt Jezus verhalenderwijs toegankelijk hoe tegen de andere medemens aan te kunnen kijken door een religieuze buitenstaander die onbaatzuchtig actief optreedt en zelf juist als de naaste voor het slachtoffer verschijnt (Luk 10:29-37). Gelovigen leren hier van een buitenstaander met andere ogen naar hun medemensen te kijken en hen te ontmoeten. Door dit 'zieltjes winnen' te noemen mist Edward Wilson toch het punt.

\section{Tegenstrijdige belangen}

De auteur verklaart geen financiële of persoonlijke belangen te hebben die hem ongepast kunnen hebben beïnvloed bij het schrijven van dit artikel.

\section{Literatuurverwijzingen}

Aristoteles, 1941, The basic works of Aristotle, Richard McKeon (ed.), Random House, New York.

Bird, A., 1998, Philosophy of science, UCL Press, London. http://dx.doi. org/10.4324/9780203165348

Boethius, A.N.S., 1973, Consolatio Philosophiae, Heinemann, London. (Loeb edition).

Bowker, J.W., 2005, The sacred neuron: Extraordinary new discoveries linking science and religion, I.B. Taurus, London, New York.

Brakel, J. van, 1998, De wetenschappen: Filosofische kanttekeningen, Universitaire Pers/Van Gorcum, Leuven/Assen.

Brom, L.J. van den, 2004, 'Theologie als verbeelding over grenzen heen', Nederlands Theologisch Tijdschrift 58(4), 273-291.

Brom, L.J. van den, 2012, 'Doordacht doorgaan met spreken over God', Nederduitse Gereformeerde Teologiese Tydskrif 53, suppl. 3. http://ngtt.journals.ac.za/pub/ article/view/230

Brooke, J.\& Cantor, G., 1998, Reconstructing nature: The engagement of science and religion, T\&T Clark, Edinburgh

Brümmer, V., 2008, What are we doing when we pray?, Ashgate, Aldershot.

Dawkins, R., 2004, The Ancestor's Tale: A pilgrimage to the dawn of life, Orion, London. Dawkins, R., 2006, The God delusion, Bantam, London.

Dennett, D., 1991, Consciousness explained, Little Brown, Boston. PMCid:1535764

Haraway, D., 1991, Simians, cyborgs, and women: The reinvention of nature, Free Association Press, London.

Harré, R., 1972, The philosophies of science: An introductory survey, Oxford University Press, Oxford.

Hawking, S., 1988, Het heelal, verleden en toekomst van ruimte en tijd, Uitgeverij Bert Bakker, Amsterdam. (Ned. vert. van A brief history of time, Bantam, London, 1988).

Hegel, G.W.F., [1807] 1937, Phänomenologie des Geistes, Johannes Hoffmeister (Hrsg.), Felix Meiner Verlag, Leipzig.

Hick, J. (ed.), 1964, The existence of God, Macmillan, New York, London. PMCid:1814261

Lovejoy, A.O., 1936, The great chain of being, Harvard University Press, Cambridge MA.

Newberg, A. \& d'Aquili, E., 2001, Why God won't go away: Brain science and the biology of belief, Ballantine, New York. PMCid:114592

Partee, C., 2008, The theology of John Calvin, Westminster John Knox, Louisville. Persinger, M.A., 1987, Neuropsychological bases of God beliefs, Praeger, New York.

Persinger, M.A., 1993, 'Vectorial cerebral hemisphericity as differential sources for the sensed presence, mystical experiences and religious conversions', Perceptual and Motor Skills 76, 915-930.http://dx.doi.org/10.2466/pms.1993.76.3.915, PMid:8321608

Persinger, M.A., 2006, 'Experimental facilitation of the sensed presence is predicted by the specific patterns of the applied magnetic fields, not by suggestibility: Reanalysis of 19 experiments', International Journal of Neuroscience 116, 10791096. http://dx.doi.org/10.1080/00207450600808800, PMid:16861170

Plato, 1980, Verzameld werk, vertaald door Xaveer de Win, De Nederlandse Boekhandel, Antwerpen.

Putnam, H., 1981, Reason, truth and history, Cambridge University Press, Cambridge. http://dx.doi.org/10.1017/CBO9780511625398

Robinson, H. Wheeler, 1956, Religious ideas of the Old Testament, rev. L.H. Brockington, Duckworth, London.

Rosenberg, A. \& McShea, D., 2008, Philosophy of biology: A contemporary introduction, Routledge, New York, London.

Runehov, A.L.C., 2007, Sacred or neural? The potential of neuroscience to explain religious experience, Vandenhoeck \& Ruprecht, Göttingen.

Russell, B., [1935] 1971, Religion and science, Oxford University Press, Oxford.

Smedes, T.A., 2004, Chaos, complexity, and God. Divine action and scientism, Peeters, Leuven.

Stenmark, M., 2001, Scientism: Science, ethics and religion, Ashgate, Aldershot.

Watts, F., 2002, Theology and psychology, Ashgate, Aldershot.

Wilson, D.S., 2007, Evolution for everyone: How Darwin's theory can change the way we think about our lives, Delacorte, New York. (Kindle edition).

Wilson, E.O., 1978, On human nature, Harvard University Press, Cambridge, MA.

Wilson, E.O., 1998, Consilience: The unity of knowledge, Knopf, New York.

Wilson, E.O., 2012, The social conquest of earth, Liveright, New York, London. (Kindle edition). 